\title{
STRATEGI MATA PENCAHARIAN NELAYAN MASYARAKAT DESA TABATAN KECAMATAN JENAMAS KABUPATEN BARITO SELATAN
}

Oleh:

Irma dwina

Pendidikan IPS, FKIP, Universitas Lambung Mangkurat, Banjarmasin, Indonesia

Email: 1810128320008@mhs.ulm.ac.id

\begin{abstract}
ABSTRAK
Penelitian ini bertujuan untuk mengetahui: 1) strategi mata pencaharian nelayan masyarakat desa tabatan dalam memenuhi kebutuhan untuk bertahan hidup, 2) bentuk-bentuk mata pencaharian atau pekerjaan sampingan para nelayan, 3) permasalahan yang terdapat pada desa tabatan. Penelitian ini dilakukan di Desa Tabatan Kecamatan Jenamas Kabupaten, Barito Selatan Provinsi, Kalimantan Tengah. Teknik mengumpulkan data yang digunakan peneliti adalah melakukan observasi, wawancara dan mengamati aktivitas masyarakat desa dalam pemenuhan kebutuhan hidup. Mayoritas masyarakat desa tabatan bekerja sebagai nelayan, yaitu pekerjaan yang sangat bergantung terhadap faktor alam seperti kondisi iklim yang sering berubah. Kondisi iklim dapat mempengaruhi hasil tangkapan ikan nelayan dan hal tersebut berpengaruh terhadap penghasilan masyarakat yang bekerja sebagai nelayan. Hasil penelitian ini memperlihatkan bahwa (1) masyarakat memiliki strategi dalam penggunaan alat penangkap ikan dengan menyesuaikan kondisi iklim yang sedang terjadi (2) sebagian nelayan masyarakat desa juga memiliki pekerjaan sampingan seperti budidaya sarang burung walet dan budidaya ikan (3) desa tabatan memiliki keterbatasan infrastruktur seperti tidak adanya listrik pada desa ini dan jarak desa yang cukup jauh dengan pusat kota.
\end{abstract}

\section{Kata Kunci: Strategi, Mata Pencaharian, dan Nelayan \\ PENDAHULUAN}

Seiring berjalannya waktu kehidupan manusia mengalami perkembangan dan perubahan. Soekanto (1990:332-337) dalam Ngafifi (2014) menjelaskan pendapat para ahli sosiologi dan antropologi satu diantara pendapat tersebut yaitu pendapat Gillin dan Gillin, yang mengartikan bahwa perubahan sosial adalah suatu variasi dari cara hidup yang telah diterima masyarakat, baik karena perubahan-perubahan kondisi geografis, kebudayaan material, komposisi penduduk, dan ideologi maupun karena adanya difusi ataupun penemuan-penemuan baru dalam masyarakat. Lahirnya penelitian ini dilatarbelakangi banyaknya permasalahan-permasalahan yang ditemui penulis dari berbagai faktor yang terdapat pada masyarakat desa tabatan. Mulai dari faktor sosial yang terdiri dari masalah ekonomi, dan pendidikan. Masalah ekonomi yaitu ketidakstabilannya pekerjaan karena rata-rata masyarakat bekerja sebagai nelayan yang sangat tergantung terhadap kondisi iklim. Masalah pendidikan sangat 
terkait dengan masalah ekonomi, masyarakat yang tergolong ekonominya rendah, tidak dapat membiayai anaknya untuk melanjutkan pendidikan ke jenjang yang lebih tinggi.

Daya tarik masyarakat untuk tinggal dan menetap di wilayah ini karena lokasinya berdekatan dengan sungai dan memiliki sumber daya ikan yang melimpah sehingga memiliki potensi ekonomi yang cukup. Sebagian besar pemenuhan kebutuhan hidup masyarakat desa tabatan bersumber dari hasil tangkapan ikan. Pemenuhan kebutuhan hidup termasuk dalam memenuhi kebutuhan jasmani dan rohani (Dini Yuniarti, dkk. 2020). Selain mereka konsumsi hasil tangkapan mereka juga mereka jual kepada para pedagang ikan. Kondisi iklim yang tidak menentu dan sering berubah sangat mempengaruhi aktivitas para nelayan dalam menangkap ikan. Untuk mengatasi hal tersebut para nelayan membuat berbagai strategi dalam menangkap ikan.

Namun perkembangan yang terlihat jelas adalah dari strategi dan alat nelayan dalam menangkap ikan. Alat yang mereka gunakan dalam menangkap ikan terbilang masih menggunakan alat tradisional. Para nelayan memiliki kemampuan dalam membaca kondisi iklim. Jika musim penghujan masyarakat menggunakan alat penangkap ikan berupa temburu, lalangit, lukah, lunta, dan sebagainya.

Dari paparan diatas, dapat dilihat bahwa kecenderungan nelayan masyarakat desa tabatan dalam menangkap ikan memiliki kemampuan dalam membaca kondisi iklim sehingga mampu merencanakan strategi dalam menangkap ikan di berbagai kondisi iklim. Jenis yang mereka lakukan disini merupakan hubungan sosial-ekonomi mereka.

\section{LANDASAN TEORI}

\section{Strategi}

Istilah strategi dapat dimaknai sebagai rencana rancangan atau taktik yang digunakan untuk mencapai suatu hal yang diinginkan. Menurut Effendy (2007:32) strategi adalah suatu perencanaan dan manajemen guna mencapai suatu tujuan. Akan tetapi untuk mencapai tujuan tersebut strategi tidak berperan layaknya peta menunjukkan arah saja, melainkan harus mampu menunjukkan taktik operasionalnya. (Amiluddin, 2018). Dalam sumber lain juga menjelaskan bahwa strategi mencakup secara keseluruhan seperti gagasan, rencana, dan aktivitas di dalamnya. Menurut Mintzberg (2007) dalam Amiluddin (2018:14) konsep strategi itu 
minimalnya harus mencakup lima makna yang saling terkait dimana strategi adalah suatu:

a. Perencanaan untuk semakin memperjelas arah yang ditempuh suatu organisasi secara rasional dalam mewujudkan tujuan-tujuan jangka panjang.

b. Acuan yang berkaitan dengan penilaian konsistensi ataupun inkonsistensi perilaku serta tindakan yang dilakukan oleh organisasi.

c. Sudut yang diposisikan oleh organisasi saat memunculkan aktivitasnya

d. Suatu perspektif yang menyangkut visi yang terintegrasi antara organisasi dengan lingkungannya yang menjadi batas bagi aktivitasnya.

e. Rincian langkah taktis organisasi yang berisi informasi untuk mengelabui para pesaing.

Jadi, strategi merupakan suatu hal yang penting guna mendukung tercapainya suatu tujuan yang diinginkan. Menurut Amiluddin, Strategi mendukung sesuatu yang unik dan berbeda dari lawan. Sehingga strategi dapat pula mempengaruhi kesuksesan masing-masing perusahaan pula karena pada dasarnya strategi dapat dikatakan sebagai rencana untuk jangka panjang. (Amiluddin, 2018)

\section{Mata Pencaharian}

Mata pencaharian adalah pekerjaan suatu penduduk sebagai aktivitas pokok dalam pemenuhan kebutuhan hidupnya. Menurut kamus besar bahasa indonesia (KBBI) arti dari sistem mata pencaharian merupakan pokok pekerjaan yang menjadi pokok penghidupan. Untuk menunjang kehidupan dalam memenuhi kebutuhan masyarakat memiliki mata pencaharian utama. Sehingga terdapat suatu wilayah yang memiliki sistem mata pencaharian yang khas. Misalnya seperti masyarakat yang tinggal di pesisir, mayoritas masyarakat bekerja sebagai nelayan dengan peralatan tertentu dalam menangkap ikan. Seperti masyarakat desa tabatan mayoritas masyarakatnya bekerja sebagai nelayan. Mata pencaharian masyarakat ini memiliki corak yang sederhana, seperti peralatan yang dipakai yang sebagian masih memakai alat tradisional. Selain itu masyarakat dapat membaca kondisi iklim sehingga mampu menyesuaikan dengan alat yang akan digunakan untuk menangkap ikan. 


\section{METODE PENELITIAN}

Penelitian ini menggunakan pendekatan kualitatif yang bertujuan untuk mendeskripsikan fakta-fakta yang ada di lapangan secara jelas mengenai aktivitas masyarakat (Yuniarti, dkk 2020). Pemilihan pendekatan kualitatif adalah berdasarkan pengungkapan faktor alam (Subiyakto, dkk. 2020). Penelitian ini terdorong karena ketertarikan penulis terhadap strategi mata pencaharian masyarakat desa tabatan dalam pemenuhan kebutuhan hidupnya dan tetap tinggal menetap di desa ini. Dalam mengumpulkan informasi maka peneliti melakukan observasi dan pengamatan, terhadap aktivitas masyarakat desa. Teknik analisis data dilakukan secara kualitatif dengan cara mengkategori, mengklasifikasikan berdasarkan kaitannya secara logis dengan permasalahan penelitian (bambang subiyakto \& mutiani, 2019). Dengan mendeskripsikan berbagai strategi mata pencaharian masyarakat desa tabatan, tentang bentuk-bentuk mata pencaharian mereka, pekerjaan sampingan yang mereka lakukan serta mendeskripsikan permasalahan apa saja yang terdapat pada desa tabatan.

\section{HASIL PENELITIAN DAN PEMBAHASAN}

Penelitian ini dilakukan di Desa Tabatan. Desa Tabatan merupakan desa terpencil yang terdapat di Kabupaten Barito Selatan, Provinsi Kalimantan Tengah. tepatnya di bantaran sungai barito dengan luas kurang lebih $200.00 \mathrm{~km}^{2}$. Jarak desa tabatan dengan pusat ibu kota berjarak kurang lebih 375,4 kilometer dan jarak desa dengan kota kurang lebih sekitar 243,3 Kilometer. Mata pencaharian masyarakat desa tabatan mayoritasnya adalah bergerak di bidang perikanan dan pertanian. Perikanan sebanyak 33 jiwa, sisanya bergerak pada bidang pertanian 39 jiwa, di bidang PNS 5 jiwa, bidang perdagangan 8 jiwa, pekerjaan lain ada 182 jiwa, dan yang belum bekerja sebanyak 111 jiwa. Secara lengkap untuk mengetahui komposisi struktur mata pencaharian masyarakat desa tabatan dapat dilihat pada tabel berikut ini:

\begin{tabular}{|c|c|c|}
\hline No & Mata pencaharian & Jumlah Jiwa \\
\hline 1 & PNS & 5 \\
\hline 2 & Perikanan (nelayan) & 33 \\
\hline 3 & Pertanian (petani) & 8 \\
\hline 4 & berdagang & 182 \\
\hline 5 & Pekerjaan lain & 39 \\
\hline
\end{tabular}




\begin{tabular}{|c|c|c|}
\hline 6 & Belum bekerja & 111 \\
\hline
\end{tabular}

Sumber: data administrasi desa tabatan kecamatan jenamas kabupaten barito selatan tahun 2020

Kondisi topografi desa tabatan berada pada dataran yang rendah dan rentan terkena banjir musiman. Desa tabatan merupakan desa yang sumber ekonominya berada pada sektor perikanan. Selain masyarakat bermata pencaharian sebagai nelayan, masyarakat juga membuat biji/sumur perangkap ikan yang dibuat besar seperti kolam dalam pengumpulan berbagai jenis ikan tawar, seperti ikan gabus yang akan dipanen pada musim kemarau. Sementara untuk pertanian yang baik untuk dikembangkan seperti padi, jagung dan singkong. Namun, bencana banjir yang musiman yang datang tidak menentu sangat sulit untuk diperkirakan. Sehingga banyak petani yang gagal panen.

Penelitian ini berfokus pada strategi mata pencaharian masyarakat desa tabatan dalam memenuhi kebutuhan hidupnya. Tujuannya adalah untuk memenuhi kebutuhan manusia termasuk kegiatan untuk menciptakan dan menambah kegunaan (Maulidiyah, dkk. 2020). Masyarakat desa tabatan sudah sejak dulu dikenal sebagai masyarakat maritim. Karena sebagian besar pekerjaan masyarakat desa yaitu sebagai nelayan. Secara ekonomi wilayah desa tabatan memiliki kekayaan alam berupa ikan yang melimpah, terdapat berbagai jenis ikan seperti ikan gabus, ikan patin, ikan gurame dan lain sebagainya. Sungai memberikan pengaruh yang besar terhadap berbagai aktivitas di kehidupan sehari-hari, seperti sebagai alat transportasi, dan kawasan permukiman warga (Nasrullah, 2016 dalam Norhayati, dkk. 2018). Aktivitas ekonomi meliputi kegiatan Produksi, distribusi, dan konsumsi (Dini Yuniarti, dkk. 2020). Hal inilah dapat membantu memenuhi kebutuhan dan perekonomian masyarakat desa tabatan agar mampu bertahan hidup.

\section{Strategi Nelayan Menangkap Ikan Di Desa Tabatan}

Menurut Sabenan (2007) Masyarakat di kawasan pesisir Indonesia sebagian besar berprofesi sebagai nelayan yang diperoleh secara turun-temurun dari nenek moyang mereka. Karakteristik masyarakat nelayan terbentuk mengikuti sifat dinamis sumberdaya yang digarapnya. Selain itu, resiko usaha yang tinggi menyebabkan masyarakat nelayan hidup dalam suasana alam yang keras yang selalu diliputi ketidakpastian dalam menjalankan usahanya (dalam Wasak, 2010:1339). 
Bekerja sebagai nelayan adalah pekerjaan yang bergantung terhadap faktor alam seperti kondisi iklim. Kondisi iklim dapat mempengaruhi hasil dari tangkapan ikan dan hal tersebut berpengaruh terhadap penghasilan masyarakat yang bekerja sebagai nelayan. Para nelayan setidaknya harus memiliki kemampuan dalam membaca kondisi iklim, sehingga apapun kondisi iklim para nelayan desa tabatan tetap dapat bekerja atau melakukan penangkapan ikan di sungai. Dalam (Ali Imron, 2012) Perubahan iklim yang terjadi merupakan fenomena alamiah yang menunjukkan tingkat ekstremitas yang sangat tinggi serta dapat menimbulkan dampak sosial ekonomi terhadap masyarakat yang bekerja sebagai nelayan. Perubahan iklim yang dihadapi masyarakat nelayan adalah sebagai bentuk adaptasi secara alamiah.

Seperti yang saya ketahui, jika memasuki iklim penghujan dan air naik (memasuki banjir musiman) maka para nelayan akan mempersiapkan alat penangkap ikan, misalnya seperti Tamburu. Tamburu dibuat berupa jaring yang berbentuk persegi empat terbuat dari kawat besi yang dijalin secara manual oleh orang yang ahli dalam membuatnya. Tamburu di pasang di sungai dikaitkan dengan beberapa pelampung, sehingga tamburu tetap mengapung di air. Ikan yang dihasilkan para nelayan adalah berupa ikan sepat. Ikan yang didapat bisa langsung dijual atau bisa juga untuk diawetkan menjadi ikan asin. Di bawah ini akan saya jelaskan beberapa peralatan menangkap ikan pada musim penghujan (banjir musiman) adalah sebagai berikut:

1) Tamburu atau tempirai, adalah alat penangkap ikan yang dibuat berupa jaring yang berbentuk persegi empat terbuat dari kawat besi yang dijalin secara manual oleh orang yang bisa membuatnya. Tamburu di pasang di sungai dengan dikaitkan beberapa pelampung di atasnya sehingga tamburu tetap mengapung di air. Ikan yang dihasilkan para nelayan adalah berupa ikan sepat, udang, dan lainnya.

2) Lukah, adalah alat penangkap ikan yang terbuat dari bambu yang dijalin dengan rotan membentuk lingkaran yang lonjong dan memanjang, sehingga membentuk perangkap. Dipasang dengan cara disodorkan ke air sampai tenggelam dengan tali atau turus agar tidak hanyut serta diberikan umpan untuk memancing ikan datang. dipasang ketika kondisi air naik, Ikan yang dihasilkan para nelayan biasanya berupa ikan gabus, gurame, dan lainnya.

3) Lunta, adalah alat penangkap ikan yang terbuat dari benang-benang marlon yang dijalin hingga membentuk lingkaran besar. Lunta dipakai nelayan menangkap ikan. Untuk menggunakan lunta yaitu dengan cara dilempar atau diceburkan 
hingga tenggelam dan didiamkan namun talinya tetap dipegang agar tidak lepas kemudian diangkat sampai mendapatkan ikan. Dan ikan yang didapatkan bisa bermacam-macam ikan.

4) Banjur, adalah alat penangkap ikan yang terbuat dari kayu. banjur mirip seperti alat pancing namun banjur pendek. Banjur dipasang ketika air pasang atau musim penghujan. Ikan yang dihasilkan bermacam-macam, ikan gabus, lele, dan ikan air tawar lainnya.

5) Lalangit, adalah alat penangkap ikan yang terbuat dari benang nilon diberi penyangga kayu di samping sampingnya. Ikan yang didapatkan biasanya adalah ikan papuyu. Dipasang di air yang kemudian diberi umpan untuk memancing ikan datang dan terperangkap pada benang-benang nilon

Peralatan tersebut dipakai para nelayan ketika datangnya banjir musiman atau masuknya musim penghujan. Hasil tangkapan ikan selain untuk mereka konsumsi juga mereka jual kepada paiwakan. Paiwakan adalah orang yang membeli hasil tangkapan ikan para nelayan (pedagang ikan). Penghasilan yang didapatkan para nelayan relatif rendah. Karena harga jual ikan sendiri rendah atau tergantung jenis ikan itu sendiri.

Berdasarkan hasil wawancara penghasilan yang didapatkan masyarakat sangat tidak menentu. Tergantung hasil tangkapan ikan yang mereka peroleh. Selain itu harga ikan pun sering naik turun. Sebagian masyarakat desa tabatan memiliki biji/sumur. Sumur yang dibuat sebagai cadangan untuk musim kemarau sehingga tetap mendapatkan penghasilan. Saat banjir datang ikan-ikan akan menyebar, dan jika air surut ikan-ikan akan terperangkap di dalam sumur tersebut. Sehingga ketika musim kemarau tiba masyarakat dapat panen ikan yang terperangkap di dalam sumur tersebut. Ikan yang dihasilkan lumayan banyak, yang ikan tersebut kemudian dijual kepada pedagang ikan.

\section{Bentuk-Bentuk Mata Pencaharian Sampingan Nelayan Masyarakat Di Desa Tabatan}

1) Nelayan. Sebagian besar masyarakat bermata pencaharian menangkap ikan, namun seiring berjalannya waktu ikan yang terus ditangkap semakin berkurang, dan ikan yang didapat nelayan pun tidak sebanyak dulu. 
2) Beternak hewan, sebagian masyarakat juga ada yang beternak sebagai pekerjaan sampingan selain menangkap ikan. Sehingga masyarakat tetap mendapatkan penghasilan. Ternak masyarakat antara lain: ternak itik, ayam, dan sebagian juga ada ternak kerbau namun hanya sedikit masyarakat yang beternak kerbau karena untuk beternak kerbau perlu modal yang besar.

3) Sarang burung walet, sebagian besar masyarakat desa tabatan juga melakukan budidaya sarang burung walet. Dengan dibangun gedung tinggi yang bertingkat didukung dengan audio tiruan suara burung walet untuk memancing agar burung masuk dan bersarang di dalam gedung tersebut. Biasanya untuk panen sarang burung dapat dilakukan 1-2 bulan sekali.

4) Budidaya ikan toman, selain itu ada juga masyarakat yang membudidayakan ikan toman. Ikan-ikan toman yang masih kecil dikurung di dalam kurungan yang terbuat dari kayu, dan di labuh-kan di air sehingga kurungan ikan tetap mengepung, ikan-ikan tersebut diberi makan setiap harinya. Jika ikan sudah besar maka dapat dipanen untuk dijual.

5) Mengayu, mengayu adalah kegiatan mencari kayu galam untuk dijadikan sebagai kayu bakar yang dipotong-potong sedemikian rupa kemudian diikat untuk dijual.

6) Bekerja sebagai buruh sawit, sebagian masyarakat yang kurang pandai dalam menggunakan alat tertentu untuk menangkap ikan. Mereka bekerja sebagai buruh sawit. Bekerja sebagai buruh sawit ini tidak hanya laki-laki namun juga perempuan (para ibu-ibu) dengan tujuan agar mendapatkan penghasilan lebih.

7) Berkebun, sebagian masyarakat desa tabatan juga ada yang berkebun, meski tidak banyak yang melakukannya, seperti berkebun pisang, jagung, dan lain sebagainya.

\section{Permasalahan Yang Terdapat pada Masyarakat Desa Tabatan}

1) Tidak adanya tenaga listrik, sejak jaman dulu hingga sekarang desa tabatan belum merasakan adanya listrik, dikarenakan desa tabatan merupakan desa terpencil di kabupaten barito selatan dan letaknya yang lumayan jauh dari pusat kota dan pusat ibu kota. Untuk sumber energi hanya dengan lampu mesin yang dihidupkan ketika sore hari hingga sekitar pukul 10.00 malam untuk mengisi daya baterai handphone. Untuk penerangan seluruh masyarakat menggunakan tabir surya yang energinya bersumber dari cahaya matahari. Tidak adanya listrik inilah membuat desa tabatan tertinggal. selain itu, sarana pendidikan yang masih menggunakan 
media tradisional, dan jangkauan internet yang sulit membuat kualitas pendidikan yang kurang maju.

2) Transportasi, selain itu di desa tabatan hanya ada transportasi air untuk menuju ke suatu wilayah lain, dan transportasi air seperti speedboat juga masih minim meskipun taksi air untuk menuju kota ada setiap hari tapi hanya ada satu taksi saja dalam satu harinya.

3) Pendidikan, jenjang pendidikan yang ada di desa hanya ada tiga jenjang saja, yaitu taman kanak-kanak (TK), sekolah dasar (SD), dan sekolah menengah pertama. Sehingga jika ingin menempuh pendidikan yang lebih tinggi seperti sekolah menengah atas (SMA) maka para pelajar perlu ke kecamatan atau ke wilayah lain. Sekaligus tinggal disana karena jarak desa ke kecamatan lumayan jauh.

4) Sarana dan prasarana pendidikan pun kurang memadai seperti yang saya ketahui sekolah tidak memiliki perpustakaan, laboratorium indoor dan lain sebagainya.

\section{SIMPULAN}

Masyarakat desa tabatan memiliki strategi mata pencaharian. Sebagian besar masyarakat desa tabatan memang bermata pencaharian sebagai nelayan. Namun seiring berjalannya waktu, ikan yang terus menerus di tangkap pun semakin berkurang. Bekerja sebagai nelayan sangat bergantung terhadap kondisi alam. Iklim yang sering berubah dapat menghambat pekerjaan para nelayan dalam menangkap ikan. Oleh karena itu masyarakat memakai berbagai peralatan dalam menangkap ikan. Selain itu masyarakat desa tabatan juga memiliki pekerjaan sampingan, seperti bekerja sebagai buruh, beternak, mengayu, budidaya ikan, budidaya sarang burung walet, berdagang dan lain sebagainya. 


\section{Daftar Pustaka}

Amiluddin,. (2018). Desa, S. D. M. P. M., \& Pasipasi, K. L. T. Departemen Antropologi Fakultas Ilmu Sosial Dan Ilmu Politik Universitas Hasanuddin.

Hs, Ali, Imran. (2012). Strategi dan usaha peningkatan kesejahteraan hidup nelayan Tanggulsari Mangunharjo Tugu Semarang dalam menghadapi perubahan iklim. Jurnal Riptek, 6.

Maulidiyah, M., Subiyakto, B., \& Hasanah, M. (2020). Economic Activities in The Kebun Rambutan Rakyat Sungai Lulut as a Learning Resource on Social Studies. The Kalimantan Social Studies Journal, 1(2), 175-183.

Norhayati, N., Abbas, E. W., \& Putra, M. A. H. (2019). Social Interaction Pattern Jelai Riverbanks South Basirih. The Innovation of Social Studies Journal, 1(1), $12-20$

Ngafifi, M. (2014). Kemajuan teknologi dan pola hidup manusia dalam perspektif sosial budaya Jurnal Pembangunan Pendidikan: Fondasi dan Aplikasi, 2(1).

Sada, H. J. (2017). Kebutuhan dasar manusia dalam perspektif pendidikan Islam. Al Tadzkiyyah: Jurnal Pendidikan Islam, 8(2), 213-226.

Subiyakto, B., Mutiani, M., Faisal, M., \& Mutaqin, M. A. (2020). Social Interaction of Jukung Craftsmen in Pulau Sewangi, Alalak, Barito Kuala. The Innovation of Social Studies Journal, 1(2), 102-110.

Subiyakto, B., \& Mutiani, M. (2019). Internalisasi nilai pendidikan melalui aktivitas masyarakat sebagai sumber belajar ilmu pengetahuan sosial. Khazanah: Jurnal Studi Islam dan Humaniora, 17(1), 137-166.

Wasak, M. P. (2010). Keadaan Sosial-Ekonomi Masyarakat Nelayan di Desa Kinabuhutan Kecamatan Likupang Barat. Kabupaten Minahasa Utara, Sulawesi Utara. Pacific Journal, 3(5), 958-962.

Yuniarti, D., Subiyakto, B., \& Putra, M. A. H. (2020). Economic Activities in Kuin Floating Market as a Learning Resource on Social Studies. The Kalimantan Social Studies Journal, 1(2), 130-140. Singkat XII, (4). 